\title{
Implementasi Program Pemberdayaan Usaha Garam Rakyat (PUGAR) di Desa Kedungmutih Kecamatan Wedung Kabupaten Demak Tahun 2011- 2013
}

\section{The Implementation of People's Salt Business Empowerment Program (PUGAR) in Kedungmutih Village Wedung Su-district Demak Regency in 2011- 2013}

\author{
Yunita Ratna Sari \\ Universitas Diponegoro Semarang \\ yunitaratna36@yahoo.com
}

\begin{abstract}
Abstrak
Adanya impor garam nasional yang hampir $50 \%$ yang dilakukan oleh Pemerintah untuk memenuhi kebutuhan garam nasional yang meningkat setiap tahunnya, menyebabkan petambak garam semakin hidup dalam kondisi yang tidak sejahtera. Kondisi petambak garam yang meprihatinkan, salah satunya di Desa Kedungmutih. Desa Kedungmutih dari dulu sampai sekarang dikenal sebagai desa kantong kemiskinan karena mayoritas masyarakat bermata pencaharian sebagai nelayan dan petambak garam yang hanya mengandalkan hasil garam untuk memenuhi kebutuhan hidup sehari- hari. Oleh karena itu, adanya program PUGAR yang dilaksanakan mulai tahun 2011 di Desa Kedungmutih, diharapkan dapat meningkatkan kesejahteraan petambak garam. Penelitian ini bertujuan untuk mengetahui pelaksanaan program PUGAR di Desa Kedungmutih, hambatan yang timbul dalam pelaksanaan program PUGAR di Desa Kedungmutih, Kecamatan Wedung, Kabupaten Demak Tahun 2011- 2013. Metode penelitian yang digunakan adalah kualitatif eksploratif. Sumber data diperoleh dari data primer yaitu melalui wawancara dengan informan atau key person dengan teknik snowball sampling. Sedangkan data sekunder berasal dari data dokumen, arsip dan sumber lain yang berhubungan dengan penelitian. Teknik analisa yang digunakan dalam penelitian ini adalah analisa data kualitatif dengan penganalisaan dalam bentuk penggambaran dan penarikan kesimpulan atas gejala yang diteliti. Hasil penelitian menunjukkan bahwa program "PUGAR" di Desa Kedungmutih yang dilaksanakan tahun 2011- 2013 kurang optimal karena hingga saat ini kendala dalam pelaksanaan program yang belum bisa terselesaikan yaitu petambak garam masih mengalami kesulitan dalam menggunakan teknologi garam, pemasaran garam masih terjerat tengkulak serta kualitas garam rakyat belum mencapai kualitas terbaik yaitu (KW 1). Adapun rekomendasi yang bisa diberikan yaitu Tenaga Pendamping harus melakukan pendampingan dalam penggunaan teknologi garam yang digunakan oleh petambak garam langsung praktek ke tambak garam dan Pemerintah harus mulai fokus dalam mendirikan KOGAR (Koperasi Garam Rakyat).
\end{abstract}

Kata Kunci: Implementasi, Pemberdayaan, Petambak garam

\begin{abstract}
The salt importation done by the government in order to fulfill the national need for salt which increases every year has caused salt farmers live in a poor condition, like the ones living in Kedungmutih village. This village has been known as a pocket of poverty
\end{abstract}


because its people, working as a fisherman and salt farmer, only rely on salt product to fulfill their daily need. PUGAR program held in 2011 at Kedungmutih village was hoped to be able to increase the salt farmers' prosperity. The purpose of this research is to know how PUGAR program is implemented and its obstacles when held at Kedungmutih village, Wedung sub-district, Demak regency in 2011-2013. This research used qualitative-explorative method. There were two kinds of data, the primary data, collected from interview with the informant or key person using snowball samplings and the secondary data, collected from documents, archives, and other sources related to the research. Technique of analysis used in this research was qualitative data analysis conducted in the form of description and conclusions of the researched phenomena. The result of the research showed that "PUGAR" program at Kedungmutih village held in 2011-2013 is less optimal because there are unfinished problems. These problems are salt farmers' inability in applying technology in salt production, problems in marketing due to the existence of middlemen, and salt farmers' inability to produce the best quality salt (KW1). The given recommendations are that the Salt Farmers Assistant Team should assist salt farmers in applying technology in salt farming and that it is necessary for the government to establish salt farmers' cooperative (KOGAR).

\section{Keywords: Implementation, Empowerment, Salt Farmers}

\section{A. Pendahuluan}

Indonesia merupakan negara kepulauan terbesar di dunia karena memiliki luas laut dan jumlah pulau yang besar. Indonesia memiliki 17.504 pulau dan panjang garis pantai $140.000 \mathrm{~km}$ dengan luas wilayah laut yang mendominasi total luas territorial Indonesia sebesar 7,7 juta $\mathrm{km}^{2} .{ }^{1}$ Salah satu sumber daya mineral yang berasal dari air laut yaitu garam. Potensi lahan garam di Indonesia mencapai 68.754,16 ha. Lahan garam tersebut, menyebar di sembilan provinsi yaitu Nanggroe Aceh Darussalam (NAD), Jawa Barat, Jawa Tengah, Jawa Timur, Bali, Nusa Tenggara Barat (NTB), Nusa Tenggara Timur (NTT), Sulawesi Selatan serta

\footnotetext{
${ }^{1}$ Kementrian Kelautan dan Perikanan. 2011."Pusat Data Statistik dan Informasi Kementrian dan Kelautan". http://statistik.kkp.go.id diakses 15 Mei 2014, pukul 13.23 WIB
}

Sulawesi Tengah. ${ }^{2}$ Menurut Dirjen KP3K KKP, kebutuhan garam dalam negeri mencapai 4 juta ton pertahun, rinciannya 1,8 juta ton garam untuk konsumsi dan 2,2 juta ton untuk industri. ${ }^{3}$ Untuk memenuhi kebutuhan garam nasional, sebagian dipenuhi oleh hasil produksi garam lokal dan sisanya dipenuhi oleh impor garam dari negara lain.

Seperti yang diketahui, realisasi impor garam untuk konsumsi 99.754 ton pada

\footnotetext{
${ }^{2}$ Muhammad Khasan Abdurrohman. 2014.

"Negara Kepulauan Impor Garam. Apa kabar Indonesia 2015."

http://writingcontest.bisnis.com diakses 15 Mei 2014, pukul 09.04 WIB.

${ }^{3}$ Boyke, P Siregar. 2014. "Penuhi Kebutuhan Garam Industri, KKP Dorong Potensi Pantai". http://wartaekonomi.co.id diakses 15 Mei 2014, pukul 19.38 WIB.
} 
tahun 2009, 597.583 ton pada tahun 2010, 923.756 ton pada tahun 2011. Sedangkan realisasi impor garam industri yaitu 1.636.699 ton pada tahun 2009, 1.590.049 ton pada tahun 2010 dan 1.691.440 ton pada tahun 2011 . $^{4}$

Adanya impor garam yang dilakukan oleh pemerintah semakin memperburuk kondisi ketidaksejahteraan dan ketidakberdayaan petambak garam. Oleh karena itu, dibutuhkan upaya dari pemerintah untuk meningkatkan kesejahteraan dan keberdayaan petambak garam. Dalam rangka mencapai swasembada garam nasional, mulai tahun 2011, KKP melaksanakan program PUGAR (Pemberdayaan Usaha Garam Rakyat) yang merupakan salah satu program PNPM Mandiri KP yang difokuskan untuk meningkatkan kesejahteraan petambak garam yang pelaksanaannya dengan prinsip bottom up artinya petambak garam yang merencanakan, melaksanakan, memonitoring, mengevaluasi kegiatan sesuai dengan mekanisme yang ditentukan. Sasaran dalam program PUGAR yaitu petambak garam yang nantinya akan dikoordinir dalam KUGAR (Kelompok Usaha Garam Rakyat) yang dalam pelaksanaannya akan didampingi oleh Tenaga Pendamping PUGAR.

\footnotetext{
${ }^{4}$ Rochwulaningsih, Yety. 2013. “ Tata Niaga Garam Rakyat Dalam Kajian Struktural". 1 Februari 2013, Jurnal Sejarah CITRA LEKHA, Vol XVII, No 1, 59 - 66. http://journal.ipb.ac.id diakses 17 Mei 2014, pukul 18.50 WIB
}

Landasan hukum yang mendasari pelaksanaan program PUGAR mengacu pada Peraturan Menteri Kelautan dan Perikanan Republik Indonesia No Per 41/ MEN/ 2011 tentang Pedoman Pelaksanaan Program Pemberdayaan Masyarakat Mandiri Kelautan dan Perikanan Tahun 2011. Menurut KKP tahun 2011, tujuan dari program PUGAR yaitu (1) memperdayakan dan meningkatkan kapasitas petambak garam rakyat yang tergabung dalam KUGAR, (2) meningkatkan akses terhadap permodalan, pemasaran, informasi, serta ilmu pengetahuan dan teknologi bagi KUGAR, (3) meningkatkan produksi garam konsumsi untuk mendukung swasembada garam konsumsi tahun 2012 dan (4) meningkatkan kualitas garam rakyat. ${ }^{5}$ Intinya melaui PUGAR diharapkan dapat meningkatkan produksi garam rakyat dengan kualitas baik sehingga dapat tercapai harga dasar garam yang ditetapkan pemerintah, dengan begitu usaha garam dapat menjadi usaha yang layak dan dapat meningkatkan kesejahteraan petambak garam. ${ }^{6}$

\footnotetext{
${ }^{5}$ Fatkhul Mukmin. 2011. "Sosialisasi PUGAR Kabupaten Demak Menuju Swasembada Garam Nasional 2012”. http://ekonomi.kompasiana.com diakses 23 Mei 2014, pukul 08.09 WIB.

${ }^{6}$ Rindayani dan Muhammad Farid Ma'ruf. 2013. "Strategi Pemberdayaan Masyarakat Melalui Program Usaha Garam Rakyat (PUGAR) Di Dinas Kelautan dan Perikanan Kabupaten Pemekasan”. Jurnal Publika, Vol 1, No 2. http://ejournal.unesa.ac.id diakses 18 Mei 2014, pukul 14.27 WIB.
} 
Salah satu sasaran lokasi program PUGAR di Indonesia yaitu Jawa Tengah yang memiliki lahan potensi garam terbesar kedua setelah Jawa Timur yaitu 2.168 ha dari total keseluruhan luas lahan garam di Pulau Jawa sekitar 10.231 ha. Ada 5 Kabupaten di Jawa Tengah yang berpotensi menghasilkan garam rakyat antara lain Kabupaten Pati, Rembang, Demak, Jepara dan Brebes. Tahun 2011, PUGAR di Jawa Tengah dilaksanakan yang melibatkan 364 KUGAR dan 3.517 petambak garam, dengan rincian di Kabupaten Pati sebanyak 199 KUGAR dan 1.934 petambak garam, Rembang 100 KUGAR dan 996 petambak garam, Demak 20 KUGAR dan 195 petambak garam, Jepara 27 KUGAR dan 212 petambak garam serta Brebes 18 KUGAR dan 180 petambak garam. ${ }^{7}$

Dipilihnya Kabupaten Demak sebagai wilayah penelitian, karena Kabupaten Demak memiliki luas lahan potensi 1.257 ha yang terbagi lahan produksi 751 ha dengan hasil produksi 60 ton / ha berasal dari 7 desa penghasil garam. ${ }^{8} \mathrm{Di}$ Kabupaten Demak ada 4 Kecamatan pesisir yang berpotensi menghasilkan perikanan yang melimpah yaitu Kecamatan Sayung, Karangtengah, Bonang dan Wedung. Meskipun ada 4

\footnotetext{
${ }^{7}$ Moki, Semarang. 2012. "Usaha Garam Di Jawa Tengah Terus Dikembangkan". http://www.kabarinvestigasi.com diakses 18 Mei 2014, pukul 20.39 WIB.

${ }^{8}$ Demak, publikasi nasional. 2011. “ DKP Demak Berdayakan Usaha Garam Rakyat "'. http://www.publiknasional.com diakses 18 Mei 2014, pukul 21.58 WIB.
}

kecamatan pesisir yang berpotensi menghasilkan perikanan, namun hanya Kecamatan Wedung yang merupakan kecamatan satu- satunya di Kabupaten Demak yang berpotensi menghasilkan garam rakyat.

Tabel 1.1 Jumlah Penduduk Miskin di Kawasan Pesisir Kabupaten Demak

\begin{tabular}{|c|c|c|c|}
\hline Kecamatan & $\begin{array}{c}\text { Jumlah } \\
\text { Penduduk } \\
\text { ( Jiwa) }\end{array}$ & $\begin{array}{c}\text { Jumlah } \\
\text { Penduduk } \\
\text { Mskin } \\
\text { ( Jiwa ) }\end{array}$ & $\begin{array}{c}\text { Persentase } \\
(\%)\end{array}$ \\
\hline Sayung & 91.334 & 35.250 & $38,59 \%$ \\
\hline Karangtengah & 56.985 & 23.178 & $40,67 \%$ \\
\hline Wedung & 96.593 & 43.816 & $45,36 \%$ \\
\hline Bonang & 79.147 & 19.225 & $24,33 \%$ \\
\hline Jumlah/ Rata-rata & 324.059 & 121.499 & $37,49 \%$ \\
\hline
\end{tabular}

Sumber: BPS Kabupaten Demak, 2005

Berdasarkan tabel 1.1 menunjukkan bahwa Kecamatan Wedung yang memiliki jumlah penduduk miskin yang paling banyak diantara 3 kecamatan pesisir lainnya di Kabupaten Demak yaitu 43.816 jiwa atau 45, $36 \%$ dari total jumlah penduduk miskin sekitar 121. 499 jiwa. Adapun alasan lain yang mendorong peneliti untuk melakukan penelitian di Desa Kedungmutih, Kecamatan Wedung, Kabupaten Demak yaitu desa tersebut merupakan desa sentral penghasil garam dan memiliki luas area tambak garam yang paling luas diantara desa penghasil garam lainnya di Kecamatan Wedung, Kabupaten Demak yaitu 192 ha dengan kemampuan produksi paling banyak di Kecamatan Wedung yakni 11.520 ton serta memiliki jumlah petambak garam 
yang paling banyak yaitu 384 petambak garam. ${ }^{9}$

Dari dulu sampai sekarang, Desa Kedungmutih dikenal sebagai desa kantong kemiskinan. Sehingga, kondisi ekonomi penduduk Desa Kedungmutih memprihatinkan dan penghasilannya kurang. Selain itu, tingkat kemiskinan penduduk di Desa Kedungmutih yang paling tinggi yaitu masyarakat pesisir. Salah satunya petambak garam. Adapun jumlah petambak garam yang miskin di Desa Kedungmutih sekitar 837 orang dari jumlah total penduduk 4.205 orang. ${ }^{10}$ Oleh karena itu, Desa Kedungmutih terutama petambak garam membutuhkan bantuan program dari pemerintah. Dalam rangka untuk meningkatkan kesejahteraan petambak garam, mulai tahun 2011, Kabupaten Demak melaksanakan program PUGAR. Adapun pelaksana program PUGAR tersebut, yaitu Dinas Kelautan dan Perikanan Kabupaten Demak.

Pelaksanaan program PUGAR di Desa Kedungmutih di nilai cukup berhasil oleh Dinas Kelautan dan Perikanan Kabupaten Demak. Hal ini didasarkan beberapa hal seperti Desa Kedungmutih mampu memproduksi garam berkualitas, bahkan garam beryodium Kedungmutih diakui lebih enak dibandingkan impor. Hal itu dibuktikan dengan permintaan pengiriman garam beryodium hingga puluhan ton ke berbagai wilayah di Jawa Tengah dan

\footnotetext{
${ }^{9}$ Buku Profil Dinas Kelautan dan Perikanan Kabupaten Demak Tahun 2011.

${ }^{10}$ Buku Profil Desa Kedungmutih Tahun 2014.
}

Jawa Barat. Permintaan konsumen semakin meningkat seperti Indramayu, Subang, setiap bulan memesan 3.000 pak atau 7,5 ton. ${ }^{11}$

Mengacu pada latar belakang permasalahan diatas, penulis tertarik untuk melakukan penelitian mengenai "Implementasi Program Pemberdayaan Usaha Garam Rakyat (PUGAR) Di Desa Kedungmutih Kecamatan Wedung Kabupaten Demak Tahun 2011- 2013”. Tujuan dari penelitian ini adalah untuk mengetahui bagaimana pelaksanaan program PUGAR Di Desa Kedungmutih, Kecamatan Wedung, Kabupaten Demak Tahun 2011- 2013 dan hambatan yang ditemui dalam pelaksanaan program tersebut.

\footnotetext{
${ }^{11}$ Sena. 2012. "Garam Wedung Berkelana Hingga Luar Kota".http://hariansemarangbanget.com diakses 24 April 2014, diakses pukul 15.58 WIB.
} 
Tabel 1.2

Data Luas Lahan Garam, Produksi Garam Rakyat dan Petambak Garam Kecamatan Wedung, Kabupaten Demak Tahun 2009

\begin{tabular}{|c|c|c|c|c|c|c|}
\hline Desa & $\begin{array}{c}\text { Luas } \\
\text { Lahan } \\
\text { Garam } \\
\text { (hektar) }\end{array}$ & $\begin{array}{c}\text { Pemilik } \\
\text { (orang) }\end{array}$ & $\begin{array}{c}\text { Penyewa } \\
\text { (orang) }\end{array}$ & $\begin{array}{c}\text { Bagi } \\
\text { hasil } \\
\text { (orang) }\end{array}$ & $\begin{array}{c}\text { Jumlah } \\
\text { total } \\
\text { (orang) }\end{array}$ & $\begin{array}{c}\text { Produksi } \\
\text { (ton) }\end{array}$ \\
\hline $\begin{array}{c}\text { Berahan } \\
\text { Wetan }\end{array}$ & 105 & 53 & 60 & 20 & 200 & 6.300 \\
\hline $\begin{array}{c}\text { Berahan } \\
\text { Kulon }\end{array}$ & 12 & 30 & - & - & 24 & 720 \\
\hline Babalan & 112 & 84 & 65 & 9 & 220 & 6.700 \\
\hline Kedungmutih & 192 & 136 & 84 & 5 & 384 & 11.520 \\
\hline Kedungkarang & 96 & 99 & 70 & 10 & 257 & 5.730 \\
\hline Kendalasem & 132 & 195 & 25 & 20 & 372 & 7.920 \\
\hline Tedunan & 25 & 20 & 5 & - & 50 & 1.500 \\
\hline Jumlah & 674 & 617 & 309 & 64 & 1.525 & 40.370 \\
\hline
\end{tabular}

Sumber : Dinas Kelautan dan Perikanan Kabupaten Demak Tahun 2011

\section{B.Landasan Teoritis}

\section{Kebijakan Publik}

Ada beberapa ahli yang berpendapat mengenai kebijakan publik. Harold Laswell dan Abraham Kaplan (1970, 71) mendefinisikan kebijakan publik sebagai "suatu program yang diproyeksikan dengan tujuan-tujuan, nilai- nilai dan praktik- praktik tertentu. Menurut Thomas R Dye (1995,2), kebijakan publik adalah segala yang dikerjakan oleh Pemerintah, mengapa mereka melakukan dan perbedaan yang dihasilkan. $^{12}$ Dalam pemahaman, kebijakan publik merupakan sesuatu yang di putuskan dan tidak diputuskan oleh Pemerintah. Pemahaman tersebut merujuk pada definisi Thomas Dye yang menyatakan bahwa kebijakan publik merupakan apapun yang dipilih oleh Pemerintah untuk dikerjakan dan

${ }^{12}$ Nugroho D, Riant. 2006. “Kebijakan Publik Untuk Negara-Negara Berkembang”. Jakarta : PT Elex Media Komputindo Kelompok Gramedia. Halaman 23-27. tidak dikerjakan. ${ }^{13}$ Berdasarkan beberapa batasan dari para ahli dapat didefinisikan kebijakan publik memiliki beberapa elemen- elemen terdiri atas (1) kebijakan sebenarnya mencakup perilaku dan harapan-harapan, (2) mencakup adanya tindakan atau ketiadaan tindakan, (3) mempunyai hasil akhir yang hendak dicapai, (4) muncul dari suatu proses yang berlangsung sepanjang waktu, (5) kebijakan negara menyangkut peran fungsi yang ada. ${ }^{14}$

\section{Tahap - Tahap dalam Proses Pembuatan Kebijakan Publik}

Ada lima tahap dalam proses pembuatan kebijakan publik sebagai berikut :

\footnotetext{
${ }^{13}$ Badjuri, Abdulkahar dan Teguh Yuwono. 2002. "Kebijakan Publik, Konsep dan Strategi". Semarang : Jurusan Ilmu Pemerintahan FISIP UNDIP. Halaman 4 ${ }^{14}$ Hosio, J.E. 2007. "Kebijakan Publik \& Desentralisasi Esai-Esai Dari Sorong". Yogyakarta : LAKSBANG. Halaman 2-4
} 
(1) Penyusunan agenda merupakan para pejabat yang dipilih dan diangkat menempatkan masalah pada agenda publik. Sebelumnya, masalah-masalah berkompetisi terlebih dahulu untuk dapat masuk ke dalam agenda kebijakan. Pada akhirnya, beberapa masalah masuk dalam agenda kebijakan para perumus kebijakan.

(2) Formulasi kebijakan merupakan masalah yang telah masuk ke agenda kebijakan kemudian dibahas oleh para pembuat kebijakan. Masalah-masalah didefinisikan untuk kemudian dicari pemecahan masalah yang terbaik. Pemecahan masalah tersebut berasal dari berbagai alternatif atau pilihan kebijakan yang ada. Pada tahap ini, masing-masing aktor akan bermain untuk mengusulkan pemecahan masalah terbaik. Dari sekian banyak alternatif yang ditawarkan oleh para perumus kebijakan, akhirnya salah satu dari alternatif kebijakan tersebut diadopsi dengan dukungan mayoritas legislatif atau keputusan peradilan. ${ }^{15}$

(3) Adopsi kebijakan seharusnya dilakukan rekomendasi kebijakan. Rekomendasi kebijakan merupakan hasil dari analisis berbagai alternatif kebijakan yang sudah diestimasikan melalui peramalan. Rekomendasi membantu menentukan kriteria dalam pembuatan pilihan dan menentukan pertanggungjawaban administratif bagi implementasi kebijakan.

${ }^{15}$ Winarno, Budi.2007. "Kebijakan Publik, Teori dan Proses”. Jakarta : PT. Buku Kita. Halaman 32-33.
(4) Implementasi kebijakan harus terdapat monitoring kebijakan. Monitoring kebijakan memberikan pengetahuan yang relavan mengenai akibat dari kebijakan yang diambil sebelumnya.

(5) Evaluasi kebijakan memberikan pengetahuan yang relavan mengenai ketidaksesuaian antara kinerja kebijakan yang diharapkan dengan yang benarbenar dihasilkan. ${ }^{16}$

\section{Implementasi Kebijakan Publik}

Implementasi kebijakan publik merupakan salah satu tahapan dari proses kebijakan publik. Ada beberapa ahli yang berpendapat tentang implementasi. Menurut kamus Webster, dalam Wahab (1991:50), implementasi menyediakan sarana untuk melaksanakan suatu kebijakan dan dapat menimbulkan dampak/ akibat terhadap sesuatu tertentu. Menurut Jones, dalam pelaksanaan kebijakan ada beberapa syarat, antara lain adanya orang (pelaksana), uang dan kemampuan operasional yang sering disebut resources.

Dari beberapa pendapat ahli maka dapat ditarik kesimpulan pengertian implementasi kebijakan merupakan pelaksanaan kebijakan yang melibatkan berbagai sumber daya manusia baik Pemerintah maupun swasta untuk mencapai tujuan bersama.

16 Dunn, William N. 2003. " Analisis Kebijakan Publik, Edisi Kedua”. Yogyakarta : GAJAH MADA UNIVERSITY PRESS. Halaman 25-27. 
Keberhasilan suatu implementasi kebijakan dapat diukur atau dilihat dari proses dan pencapaian tujuan-tujuan yang ingin diraih. Seperti yang diutarakan oleh Merrile Grindle (1980) yaitu pengukuran keberhasilan implementasi dapat dilihat dari prosesnya, dengan mempertanyakan apakah pelaksanaan program sesuai dengan yang telah ditentukan yaitu melihat pada action program dari individual projects dan yang kedua apakah tujuan program tersebut tercapai. ${ }^{17}$

Jones dalam Gaffar (1997), aktivitas implementasi kebijakan terdapat tiga macam sebagai berikut :

(1) Aktivitas pengorganisasian merupakan upaya untuk menetapkan dan menata kembali sumber daya, unitunit dan metode-metode yang mengarah pada upaya merealisasikan kebijakan menjadi hasil sesuai sasaran dan tujuan yang ingin dicapai.

(2) Aktivitas interpretasi merupakan penjelasan substansi dari kebijakan dalam bahasa yang mudah dipahami sehingga dapat diterima oleh pelaku dan sasaran kebijakan.

(3) Aktivitas aplikasi merupakan penyediaan pelayanan secara rutin dan sarana kebijakan yang ada. ${ }^{18}$

17 Agustino, Leo. 2008. "Dasar- Dasar Kebijakan Publik". Bandung : Alfabeta. Halaman 139-140.

18 Widodo, Joko. 2011. “Analisis Kebijakan Publik, Konsep dan Aplikasi Analisis Proses Kebijakan Publik”. Malang : Bayumedia Publishing. Halaman 89.

\section{Model Implementasi Kebijakan Publik}

Ada beberapa model implementasi kebijakan antara model implementai kebijakan George C. Edward III, Van Meter dan Van Horn dan Merilee S. Grindle.

\subsection{Model Implementasi Kebijakan Publik George C Edward III}

Terdapat empat variabel yang berperan penting dalam pencapaian keberhasilan implementasi kebijakan yang dikemukakan George C Edward III sebagai berikut :

a.Komunikasi yaitu setiap kebijakan akan dapat dilakukan dengan baik jika terjadi komunikasi efektif antara pelaksana program kebijakan dengan para kelompok sasaran (target groups).

b. Sumber daya yaitu setiap kebijakan harus didukung oleh sumber daya yang memadai, baik sumber daya manusia maupun finansial. Sumber daya manusia mencakup kecukupan baik kualitas maupun kuantitas implementor yang dapat melingkupi seluruh kelompok sasaran. Sumber daya finansial adalah kecukupan modal investasi atas sebuah program/ kebijakan.

c. Disposisi menunjuk karakteristik yang dimilki oleh implementor kebijakan / program.

d. Struktur birokrasi menjadi penting dalam implementasi kebijakan. Aspek struktur birokrasi mencakup 2 hal penting yaitu mekanisme dan struktur organisasi pelaksana. 


\subsection{Model Implementasi Kebijakan Publik Van Meter Van Horn}

Beberapa variabel implementasi kebijakan publik Van Meter Van Horn sebagai berikut :

a. Standar dan sasaran kebijakan, intinya apa yang hendak dicapai oleh program atau kebijakan.

b. Kinerja kebijakan merupakan penilaian terhadap pencapaian standar dan sasaran kebijakan yang telah ditetapkan di awal.

c. Sumber daya menunjukkan pada seberapa besar dukungan finansial dan sumber daya manusia untuk melaksanakan program atau kebijakan.

d. Komunikasi antar badan pelaksana menunjuk kepada mekanisme prosedur yang dicanangkan untuk mencapai sasaran dan tujuan program.

e. Karakteristik badan pelaksana menunjuk seberapa besar daya dukung struktur organisasi, hubungan dan komunikasi yang terjadi di internal birokrasi.

f. Lingkungan sosial, ekonomi dan politik menunjuk bahwa lingkungan dalam ranah implementasi dapat mempengaruhikesuksesan implementasi kebijakan itu sendiri.

g. Sikap pelaksana menunjuk Seberapa demokratis, antusias dan responsif terhadap kelompok sasaran dan lingkungan. ${ }^{19}$

\subsection{Model Implementasi Kebijakan Publik Merilee S Grindle}

Keberhasilan implementasi menurut Merilee S. Grindle dipengaruhi dua variabel besar yaitu :

a.Isi kebijakan (content of policy) mencakup (1) sejauh mana kepentingan kelompok sasaran atau target groups termuat dalam isi kebijakan, (2) jenis manfaat yang diterima oleh target groups, (3) sejauh mana perubahan diinginkan dari sebuah kebijakan, (4) apakah letak sebuah program sudah tepat, (5) apakah sebuah kebijakan telah menyebutkan implementornya dengan rinci dan (6) apakah sebuah program didukung oleh sumber daya yang memadai.

b. Lingkungan kebijakan mencakup (1) seberapa besar kekuasaan, kepentingan dan startegi yang dimilki oleh para aktor yang terlibat dalam implementasi kebijakan, (2) institusi dan rezim yang berkuasa, (3) tingkat kepatuhan dan responsivitas kelompok sasaran. ${ }^{20}$

${ }^{19}$ Indiahono, Dwiyanto. 2009. "Kebijakan Publik, Berbasis Dyanamic Policy Analisys". Yogyakarta :IKAPI DIY. Halaman 31-41.

20 Subarsono, AG. 2011. "Analisis Kebijakan Publik, Konsep, Teori dan Aplikasi". Yogyakarta : PUSTAKA PELAJAR. Halaman 93-94. 


\section{Pemberdayaan Masyarakat}

Dalam pengertian konvensional, konsep pemberdayaan sebagai terjemahan empowerment mengandung dua pengertian, yaitu (1) memberi kekuasaan, mengalihkan kekuatan atau mendelegasikan otoritas ke pihak lain, (2) atau usaha untuk memberi kemampuan atau keberdayaan. ${ }^{21}$

Ada 2 segi pengertian dari pemberdayaan yakni proses dan tujuan. Sebagai proses, pemberdayaan merupakan serangkaian kegiatan untuk memperkuat keberdayaan kelompok lemah dalam masyarakat, termasuk individu-individu yang mengalami masalah kemiskinan. Sebagai tujuan, maka pemberdayaan menunjuk pada hasil yang ingin dicapai oleh sebuah perubahan sosial yaitu masyarakat yang berdaya, memiliki kekuasaan atau mempunyai pengetahuan dan kemampuan dalam memenuhi kebutuhan hidupnya baik yang bersifat fisik, ekonomi maupun sosial seperti mampu manyampaikan aspirasi, mempunyai mata pencaharian dan berpartisipasi dalam kegiatan sosial. ${ }^{22}$

${ }^{21}$ Wrihatnolo, Randy R dan Riant Nugroho Dwidjowijoto. $2007 . \quad$ "Manajemen Pemberdayaan, Sebuah Pengantar dan Panduan Untuk Pemberdayaan Masyarakat". Jakarta : PT Elex Media Komputindo. Halaman 115.

22 Suharto, Edi. 2009. "Membangun Masyarakat Memberdayakan Rakyat, Kajian Strategi Pembagunan Kesejahteraan Sosial dan Pekerjaan Sosial". Bandung : PT Refika Aditama. Halaman 57-60.
Pemberdayaan bukan termasuk proses yang instan, tapi membutuhkan beberapa tahapan yaitu :

a.Tahap Penyadaran mencakup target yang hendak diberdayakan yang mayoritas kelompok miskin diberi "pencerahan" dalam bentuk pemberian penyadaran dan pemahaman. Seperti memberikan pengetahuan yang bersifat kognisi, belief dan healing.

b.Tahap Pengkapasitasan yang sering disebut "capacity building" atau enabling mencakup tiga hal yaitu manusia, organisasi dan sistem nilai.

c. Tahap Pendayaan meliputi target diberikan daya, kekuasaan, otoritas atau peluang. Proses pemberian daya atau kekuasaan diberikan sesuai dengan kecakapan penerima. ${ }^{23}$

\section{Metode Penelitian}

Metode yang digunakan dalam penelitian ini adalah penelitian kualitatif dengan tipe penelitian bersifat eksploratif yang digunakan untuk menggali data secara mendalam tentang implementasi program PUGAR di Desa Kedungmutih, Kecamatan Wedung, Kabupaten Demak tahun 2011- 2013. Pengambilan data primer menggunakan wawancara mendalam dengan key informants meliputi Tim Teknis PUGAR (Kasi Dinas Kelautan dan Perikanan Kabupaten Demak), Tenaga Pendamping PUGAR Desa

${ }^{23}$ Wrihatnolo, Randy R dan Riant Nugroho Dwidjowijoto. 2007. "Manajemen Pemberdayaan, Sebuah Pengantar dan Panduan Untuk Pemberdayaan Masyarakat". Jakarta : PT Elex Media Komputindo. Halaman 2-6. 
Kedungmutih, Kepala Desa Kedungmutih dan KUGAR yang terdiri dari petambak garam. Untuk memperoleh data sekunder melalui analisis dokumen seperti hasil laporan Tenaga Pendamping Program PUGAR. Kemudian data yang diperoleh dilakukan dengan melalui tahapan pengujian mulai dari Uji Kredibilitas Data, Uji Transferability Data, Uji Dependability Data, Uji Konfirmability Data. $^{24}$

\section{Hasil dan Pembahasan}

Dalam penelitian ini, penulis menggunakan beberapa konsep yang berkaitan dengan pelaksanaan program PUGAR dari teori implementasi kebijakan publik Van Meter dan Van Horn.

\subsection{Implementasi Program}

Pemberdayaan Usaha Garam Rakyat (PUGAR) Di Desa Kedungmutih, Kecamatan Wedung, Kabupaten Demak Tahun 2011- 2013

\subsubsection{Standar dan sasaran program}

Standar mengacu pada serangkaian kegiatan dalam program PUGAR dari proses awal sampai akhir program telah sesuai dengan standar program yang telah ditetapkan sebelumnya atau tidak. Dari hasil analisis yang dilakukan oleh peneliti dari temuan di lapangan bahwa serangkaian kegiatan dalam program PUGAR telah sesuai dengan standar program yang ditetapkan sebelumnya yakni pedoman teknis program PUGAR. Dibuktikan dengan ketika program PUGAR akan dilaksanakan di

24 Sugiyono.2009. "Metode Penelitian Kuantitatif, Kualitatif dan $R \quad \& \quad D$ ". Bandung : Alfabeta. Halaman 277.
Desa Kedungmutih, sebelumnya implementor program PUGAR di Kabupaten Demak melakukan sosialisasi program PUGAR untuk memberikan informasi kepada petambak garam tentang program PUGAR yang dilaksanakan pada tanggal 24 Mei 2011 di Balai Desa Kedungmutih. Dari segi pemetaan wilayah tambak garam dilakukan oleh Konsultan Pemetaan Potensi Wilayah Tambak Garam untuk membantu implementor program PUGAR yaitu Tenaga Pendamping dan Tim Teknis yang mempunyai peran utama dalam program PUGAR guna memetakan dan mengusulkan lokasi tambak garam di Kabupaten Demak yang akan dijadikan sasaran program PUGAR. Dari hasil koordinasi antara Konsultan Pemetaan Potensi Wilayah Tambak Garam dengan implementor program PUGAR dihasilkan Kecamatan Wedung yang dipilih sebagai sasaran program PUGAR karena Kecamatan Wedung merupakan Kecamatan satu-satunya yang memiliki tambak garam yang berpotensi untuk membuat garam rakyat.

Dari segi monitoring, implementor program PUGAR di Kabupaten Demak setiap tahunnya, dari tahun 2011- 2013 selalu melakukan monitoring terhadap pelaksanaan program PUGAR di Desa Kedungmutih. Monitoring yang dilakukan oleh implementor program PUGAR seperti monitoring hasil produksi garam rakyat dan pembelian barang dengan pengecekan nota, kwitansi pembelian barang ke KUGAR. Sebagai bukti, implementor program 
PUGAR di Kabupaten Demak telah melakukan monitoring misalnya tahun 2011, monitoring program PUGAR dilakukan bulan Agustus sampai September. Setelah melakukan monitoring, implementor program PUGAR di Kabupaten Demak melakukan evaluasi pelaksanaan program PUGAR di Desa Kedungmutih khususnya misalnya mengevaluasi produksi garam rakyat, pemanfaatan BLM dan target KUGAR. Implementor program PUGAR juga melakukan lokal karya yang biasanya di adakan di Aula Dinas Kelautan dan Perikanan Kabupaten Demak. Tujuan dari lokal karya tersebut yaitu mengevaluasi kegiatan yang sudah dilaksanakan, memaparkan keberhasilan dan kekurangan dari program PUGAR, target capaian program PUGAR, keseluruhan hasil lokal karya tersebut nantinya akan dijadikan rekomendasi lokal karya tingkat Provinsi dan Nasional.

Dari kegiatan lokal karya diharapkan dapat diketahui dan dievaluasi bagaimana kegiatan program PUGAR dari awal sampai akhir produksi, kendala dan permasalahan yang dihadapi, kritik dan saran terhadap program PUGAR. Pelaporan biasanya dilakukan oleh Tenaga Pendamping yang sering berinteraksi dengan petambak garam dan setiap bulannya Tenaga Pendamping membuat laporan tentang kegiatan yang telah dilaksanakan oleh petambak garam dan dilaporkan kepada Tim Teknis dan Kepala Dinas Kelautan dan Perikanan Kabupaten Demak.
Dalam program PUGAR ada 2 sasaran yaitu sasaran lokasi dan sasaran penerima manfaat program PUGAR. Berdasarkan hasil analisis peneliti bahwa penentuan dan penetapan Desa Kedungmutih sebagai sasaran lokasi program PUGAR dari tahun 2011- 2013 sudah tepat. Hal itu didasari beberapa hal antara lain Desa Kedungmutih merupaka desa yang memiliki tambak garam yang paling luas di Kecamatan Wedung yaitu 192 ha yang memiliki kemampuan memproduksi garam sekitar 11. 520 ton dan mempunyai petambak garam yang paling banyak yaitu 384 orang. Hal tersebut sesuai yang ada dalam pedoman teknis program PUGAR yakni adanya lokasi tambak garam, kegiatan produksi garam rakyat dan petambak garam yang benarbenar siap mengembangkan usaha garam rakyat.

Dari sasaran penerima manfaat program PUGAR yaitu petambak garam yang dikoordinir dalam KUGAR. Adapun sasaran penerima manfaat program PUGAR tahun 2011 terdiri dari 4 KUGAR yaitu Manfaat Sejahtera, Barokah Sejahtera, Mandiri Sejahtera dan Sejahtera Abadi yang masingmasing anggota kelompoknya 10 orang. Untuk tahun 2012, sasaran penerima manfaat program PUGAR ada 8 KUGAR terdiri dari 4 KUGAR baru meliputi Garam Kedungmutih 1, Garam Kedungmutih 2, Garam Kedungmutih 3 dan Garam Kedungmutih 4 serta 4 KUGAR lama meliputi Manfaat Sejahtera, Barokah Sejahtera, Mandiri Sejahtera dan Sejahtera Abadi. Tahun 2013, sasaran penerima manfaat 
program PUGAR terdiri dari 15 KUGAR baru meliputi Kedungmutih 5, Kedungmutih 6, Kedungmutih 7, Kedungmutih 8, Kedungmutih 9, Kedungmutih 10, Kedungmutih 11, Kedungmutih 12, Kedungmutih 13, Kedungmutih 14, Kedungmutih 15, Kedungmutih 16, Kedungmutih 17, Kedungmutih 18 dan Kedungmutih 19. Dalam penentuan dan penetapan sasaran penerima manfaat program PUGAR dinilai sudah tepat karena melalui proses seleksi yang sangat ketat dibuktikan dengan petambak garam yang tidak memenuhi syarat yang ditetapkan seperti KTP, KK, surat keterangan dari Kepala Desa yang menjelaskan petambak garam dan tupi pajak maka akan tereliminasi sehingga tidak dapat diusulkan untuk menjadi sasaran penerima manfaat program PUGAR.

Dengan serangkaian kegiatan dalam pelaksanaan program PUGAR di Desa Kedungmutih, yang dijalankan sesuai dengan pedoman teknis program PUGAR maka memberikan manfaat bagi petambak garam yang menjadi sasaran penerima manfaat program tersebut. Adapun manfaat yang diperoleh petambak garam dengan adanya pogram PUGAR antara lain petambak garam mendapat bantuan sarana dan prasarana karena PUGAR memberikan bantuan berupa dana BLM PUGAR yang nantinya digunakan dalam penyediaan sarana dan prasarana yang menunjang dalam proses pembuatan garam rakyat. Sehingga, petambak garam tidak perlu mengeluarkan modal sendiri atau meminjam uang kepada orang lain untuk membiayai proses membuat garam rakyat. Seperti yang diketahui, bahwa dalam proses awal membuat garam rakyat, biaya yang dikeluarkan sangat besar disebabkan petambak garam dalam membuat garam rakyat menggunakan cara tradisional dengan peralatan seadanya. Sebelum adanya program PUGAR, petambak garam di Desa Kedungmutih membuat garam ralyat dengan cara tradisional yang banyak menggunakan tenaga manusia untuk menaikkan air laut ke tambak garam sehingga biaya yang harus dikeluarkan sangat tidak ekonomis dan cenderung mahal. Bukti petambak garam di Desa Kedungmutih mendapat bantuan dana BLM PUGAR yaitu dana BLM PUGAR, digunakan oleh sebagian besar petambak garam untuk membeli kincir angin, slender, tombong, garuk, perbaikan gudang dan perbaikan jalan meunju tambak garam.

Manfaat lainnya yaitu petambak garam mulai mengenal berlembaga melalui pembentukan kelompok. Karena memang dalam pelaksanaan program PUGAR, petambak garam dikoordinir dalam kelompok yang disebut KUGAR (Kelompok Usaha Garam Rakyat). Dengan adanya KUGAR, diharapkan semua kepentingan yang ada dalam kelompok agar dapat mudah disampaikan dan diwujudkan oleh Dinas Kelautan dan Perikanan Kabupaten Demak sebagai pengelola program PUGAR di Desa Kedungmutih. Selain itu, agar Dinas Kelautan dan Perikanan Kabupaten Demak lebih mudah untuk melakukan 
monitoring, evaluasi dan pengawasan terhadap pelaksanaan program PUGAR di desa tersebut. Seperti yang diketahui, bahwa sebelum adanya program PUGAR di Desa Kedungmutih, petambak garam dalam membuat dan mengolah garam rakyat dilakukan individu disebabkan karena adanya pola pikir dari petambak garam bahwa dengan adanya membuat dan mengolah garam rakyat dengan individu, maka keuntungan yang didapatkan besar daripada tergabung dalam kelompok, padahal jumlah petambak garam di Desa Kedungmutih paling banyak di antara desa penghasil garam lainnya di Kecamatan Wedung yakni 300 petambak garam. Bukti bahwa petambak garam di Desa Kedungmutih mengetahui berlembaga yaitu terbentuknya KUGAR yang berjumlah 24 KUGAR di Desa Kedungmutih dari tahun 2011- 2013.

Dengan adanya pemberian bantuan program PUGAR berupa penyediaan sarana dan prasarana penunjang proses pembuatan garam rakyat, petambak garam di Desa Kedungmutih telah mampu meningkatkan produksi garam rakyat. Hal itu dibuktikan dengan sebelum adanya program PUGAR, hasil produksi garam di Desa Kedungmutih tahun 2011- 2013 sekitar 50 ton, 60 ton dan 40 ton. Setelah adanya program PUGAR, produksi garam rakyat dari petambak garam di Desa Kedungmutih mengalami kenaikan menjadi 70 ton, 80 ton dan 60 ton. Dari segi harga dan kualitas garam rakyat sama sebelum dan sesudah adanya program PUGAR yaitu Rp 250 per $\mathrm{kg}$ dan KW 3.
Meningkatnya produksi garam rakyat menyebabkan kesejahteraan petambak garam mengalami kenaikan. Karena pada dasarnya, ukuran kesejahteraan dapat dilihat dari produksi (skala usaha). Dibuktikan, apabila dihitung, pendapatan petambak garam sebagai penerima program PUGAR untuk tahun 2011 sampai tahun 2012 sekitar Rp 17.500.000 atau sekitar Rp 20.000.000 pada musim panen garam rakyat. Untuk tahun 2013, rata-rata pendapatan petambak garam sekitar Rp 15.000.000 pada musim panen garam rakyat. Apabila dibandingkan dengan sebelum mendapat program PUGAR, pendapatan petambak garam di Desa Kedungmutih sekitar Rp 12.500.000 atau sekitar Rp 15.000.00 untuk tahun 2011 sampai tahun 2012 karena produksi garamnya sekitar 50 sampai 60 ton. Untuk tahun 2013, produksi garam dari petambak garam sekitar 40 ton sehingga pendapatan petambak garam sekitar Rp 10.000.000 pada waktu panen garam rakyat.

\subsubsection{Sumber daya Implementasi}

Ada 2 sumber daya dalam pelaksanaan suatu program yaitu sumber daya implementor dan sumber daya finansial. Sumber daya implementor mengacu pada kemampuan dan kualitas implementor yang melingkupi target groups. Sedangkan, sumber daya finansial mengacu pada dana yang membiayai pelaksanaan suatu program. Dukungan kedua sumber daya tersebut sangat penting agar pelaksanaan program berjalan lancar dan efektif.

Ada 2 kategori pihak yang terlibat dalam program PUGAR di Desa 
Kedungmutih yaitu pihak desa yang terdiri dari Kepala Desa Kedungmutih dan petambak garam serta pihak dari Pemerintah terutama Dinas Kelautan dan Perikanan Kabupaten Demak yang terdiri dari Kepala Dinas Kelautan dan Perikanan Kabupaten Demak, Tim Teknis dan Tenaga Pendamping program PUGAR. Kepala Desa Kedungmutih mempunyai peran sebagai fasilitator dan koordinator di tingkat desa, petambak garam sebagai sasaran penerima manfaat program PUGAR sekaligus mendapat dampak langsung dari pelaksanaan program PUGAR, Tim Teknis berperan melakukan verifikasi calon penerima manfaat program PUGAR dan Tenaga Pendamping mempunyai peran motivator, fasilitator, komunikator selama program PUGAR berlangsung.

Dari segi sumber daya implementor dalam pelaksanaan program PUGAR di Desa Kedungmutih cukup memadai karena implementor program PUGAR merupakan lulusan Sarjana Perikanan yang mengetahui sektor penggaraman rakyat karena memang program PUGAR dibawah kendali dari Dinas Kelautan dan Perikanan Kabupaten Demak di tingkat Kabupaten. Bukti lain yang menunjukkan bahwa implementor program PUGAR memiliki kemampuan yang memadai yaitu implementor program PUGAR terutama Tenaga Pendamping yang paling sering berinteraksi dengan KUGAR mengikuti pelatihan langsung dari Kementrian Kelautan dan Perikanan mengenai program PUGAR dan cara penyuluhan di lapangan sebelum program PUGAR disampaikan kepada petambak garam. Selain itu, implementor program PUGAR sudah memahami dengan jelas tentang isi program PUGAR, tujuan dan sasaran program ini. Kemampuan implementor dalam program PUGAR juga dapat dilihat bagaimana implementor mengatasi kendala dalam menyampaikan dan mengarahkan program PUGAR yang pendidikannya rendah hanya tamat SD-SMP serta cara implementor menanggapi kritik dan saran yang muncul dari petambak garam. Selama program PUGAR di Desa Kedungmutih berlangsung, implementor dinilai cukup memadai karena dalam mengatasi hambatan dan kritik serta saran dalam pelaksanaan program PUGAR, implementor melakukan koordinasi dan menampung saran dan kritik dari petambak garam kemudian disampaikan kepada Tim Teknis dan Kepala Dinas Kelautan dan Perikanan Kabupaten Demak untuk melakukan diskusi guna mencari solusi yang terbaik.

Dari segi, sumber daya finansial dalam program PUGAR telah menjangkau semua petambak garam di Desa Kedungmutih, meskipun dalam memperoleh bantuan dana BLM PUGAR bergulir. Adapun dana yang dialokasikan untuk program PUGAR di Desa Kedungmutih tahun 2011 sekitar 200 juta untuk 4 KUGAR, 2012 berjumlah 250 juta dengan rincian 50 juta untuk 4 KUGAR lama dan 200 juta untuk 4 KUGAR baru serta tahun 2013 berjumlah 210 juta untuk 15 KUGAR. Semua dana tersebut berasal dari APBN KKP. Ketepatan penggunaan dana BLM 
PUGAR sudah tepat, dibuktikan KUGAR telah menggunakan dana tersebut untuk pembelian peralatan penunjang proses pembuatan garam rakyat seperti kincir angin, tombong, slender, garuk, perbaikan gudang dan perbaikan jalan menunju tambak garam yang sebelumnya rusak parah. Untuk kekuatan dana program PUGAR dinilai cukup untuk penyediaan sarana dan prasarana usaha garam rakyat.

\subsubsection{Komunikasi}

Hubungan implementor program PUGAR dengan pihak yang terkait dengan program, utamanya pihak desa yang terdiri dari Kepala Desa kedungmutih dan petambak garam sangat baik. Adapun cara untuk membina komunikasi tersebut yaitu melalui sosialisasi langsung kepada petambak garam, pertemuan desa dan sharing baik yang dilaksanakan di Balai Desa Kedungmutih, rumah Kepala Desa Kedungmutih maupun di Aula Dinas Kelautan dan Perikanan Kabupaten Demak guna mendiskusikan perkembangan pelaksanaan program PUGAR di Desa Kedungmutih. Sosialisasi program PUGAR di Desa Kedungmutih dilaksanakan pada $24 \mathrm{Mei}$ 2011 di Balai Desa Kedungmutih yang dihadiri 50 petambak garam. Adapun narasumber dalam sosialisasi tersebut yaitu Dinas Kelautan dan Perikanan Kabupaten Demak. Adapun yang memaparkan sosialisasi program PUGAR yaitu Ir. Heru Budiono sebagai Kabid Kelautan dan Drs. Nur Wahyudi sebagai Kepala Dinas Kelautan dan Perikanan Kabupaten Demak. Sosialisasi program PUGAR yang dilaksanakan di Desa Kedungmutih cukup efektif karena sebagian besar petambak garam mengetahui program PUGAR seperti tujuan, latar belakang adanya program dan cara mendapatkan bantuan dana dari program PUGAR.

\subsubsection{Struktur Agen Pelaksana}

Keberhasilan implementasi suatu program juga dipengaruhi oleh karakteristik agen pelaksana. Karakteristik agen pelaksana dapat dilihat dari struktur birokrasi yang mencakup 2 hal yaitu mekanisme yang berkaitan dengan SOP (Standar Operating Procedure) dan struktur organisasi pelaksana. Dalam program PUGAR, terdapat SOP yang berbentuk pedoman teknis program PUGAR yang mudah dipahami dan dilaksanakan oleh implementor program PUGAR di Desa Kedungmutih tahun 2011- 2013, sehingga segala kegiatan dalam program PUGAR mengacu pada juknis. Selain itu, setiap tahunnya juknis program PUGAR mengalami perubahan dari tahun 2011- 2013. Adapun letak perubahan tersebut yaitu dalam penggunaan teknologi yakni tahun 2011- 2012 menggunakan ramsol (zat adiktif) dan 2013 menggunakan TUF (Teknologi Ulir Filter).

Dari segi struktur organisasi pelaksana ada sedikit perbedaan. Adapun letak perbedaan tersebut yaitu tahun 2011 ada Tim Pemberdayaan Masyarakat (TPM) yang mempunyai peran melakukan verifikasi calon penerima manfaat program PUGAR, mengidentifikasi dan menyeleksi serta memverifikasi RUB dan untuk tahun 2012- 2013 ada Tim Teknis., namun dari segi perannya sama hanya namanya saja yang berbeda. Untuk mewujudkan keberhasilan 
pelaksanaan program PUGAR di Desa Kedungmutih tahun 2011- 2013, implementor tidak hanya melaksanakan kegiatan dalam program PUGAR sesuai dengan juknis tapi juga mencatat segala aktivitas kegiatan di lapangan saat pelaksanaan program PUGAR berlangsung dan diaudit oleh Dinas Kelautan dan Perikanan Kabupaten Demak.

\subsubsection{Disposisi Implementor}

Disposisi implementor merupakan sikap yang dimiliki oleh implementor terhadap target groups. Sikap implementor program PUGAR terhadap target groups yaitu selalu menempatkan KUGAR selaku target groups sebagai sasaran utama dalam segala kegiatan program PUGAR. Dibuktikan dengan petambak garam diberi pelatihan tentang cara menggunakan teknologi dalam program PUGAR, diajak studi banding ke daerah lain serta diundang rapat kemudian diberi sosialisasi tentang program PUGAR. Disamping itu, agar petambak garam tahu, mau dan mampu melaksanakan program PUGAR dengan baik dan berhasil, dibutuhkan sikap implementor yang demokratis dan responsif dalam pelaksanaan program tersebut. Selama program PUGAR berlangsung di Desa Kedungmutih tahun 2011- 2013, implementor dinilai sudah mempunyai sikap yang demokratis dan responsif. Dibuktikan dengan ketika ada kritik dan saran dari petambak garam yang dikoordinir KUGAR, implementor terutama Tenaga Pendamping memberikan respon terhadap kritik dan saran tersebut dengan menampung kritik dan saran mereka kemudian dikoordinasikan kepada implementor yang lain seperti Tim Teknis dan Kepala Dinas Kelautan dan Perikanan Kabupaten Demak.

\subsubsection{Lingkungan sosial, ekonomi dan politik}

Dari segi kondisi ekonomi petambak garam di Desa Kedungmutih memprihatinkan dan penghasilannya kurang untuk memenuhi kebutuhan sehari- hari karena sebagian besar petambak garam di desa tersebut hanya mengandalkan hasil garam untuk menopang kehidupannya, padahal dalam membuat garam rakyat sangat mengandalkan cuaca yang tidak menentu. Selain itu, SDM petambak garam di Desa Kedungmutih rendah karena mayoritas pendidikan petambak garam tamat SD- SMP. Oleh karena itu, adanya program PUGAR di Desa Kedungmutih sejak tahun 2011, direspon positif oleh petambak garam utamanya dan mendapat dukungan yang penuh dari pihak desa

Bentuk dukungan pihak desa yang terdiri dari petambak garam dan Kepala Desa paling banyak berupa partisipasi pikiran yang diberikan saat rapat maupun pertemuan tingkat desa baik yang diadakan di Balai desa maupun di Aula kantor Dinas Kelautan dan Perikanan Kabupaten Demak. Contoh bentuk partisipasi pikiran dari petambak garam yaitu memberikan usul dan pendapat pada saat rapat, pertemuan desa dengan Dinas Kelautan dan Perikanan Kabupaten maupun pada waktu sosialisasi. Sedangkan, dari segi kepatuhan, petambak garam mengikuti semua aturan dan arahan dari 
implementor program PUGAR yaitu Tim Teknis dan Tenaga Pendamping.

\subsection{Hambatan dalam Pelaksanaan Program PUGAR Di Desa Kedungmutih, Kecamatan Wedung, Kabupaten Demak Tahun 2011- 2013}

Secara umum, pelaksanaan program PUGAR di Desa Kedungmutih sudah tepat karena telah memberikan manfaat bagi petambak garam. Namun, terdapat hambatan dalam pelaksanaan program PUGAR di Desa Kedungmutih antara lain petambak garam masih mengalami kesulitan dalam menggunakan teknologi program PUGAR seperti ramsol dan TUF, pemasaran garam rakyat masih terjerat tengkulak dan kualitas garam rakyat yang masih rendah yaitu KW 3 . Adapun penyebab petambak garam di Desa Kedungmutih masih mengalami kesulitan dalam menggunakan teknologi garam yaitu pendidikan petambak garam di Desa Kedungmutih rendah, rata- rata tamat SD sampai SMP, ditambah lagi teknologi yang diberikan oleh program PUGAR terbilang baru yang mana petambak garam sebelumnya tidak pernah mengetahui dan menggunakan teknologi baru tersebut. Akibatnya, mayoritas garam rakyat yang dihasilkan oleh petambak garam sebagai penerima manfaat program PUGAR belum bisa mencapai KW 1. Dari segi kualitas, jika dibandingkan sebelum dan sesudah mendapatkan program PUGAR sama yaitu KW 3, yang membedakan yaitu adanya peningkatan produksi garam rakyat, meskipun ada garam rakyat dari petambak garam yang masuk KW 2, tapi jumlahnya sangat sedikit. Hal itu mempengaruhi harga garam rakyat yang rendah sekitar $\mathrm{Rp} 250$ per $\mathrm{kg}$. Disamping itu, pemasaran garam rakyat masih terjerat tengkulak yang membeli garam rakyat dengan harga murah dan semena- mena. Hal tersebut semakin memperburuk kondisi kesejahteraan petambak garam yang eknominya serba kekurangan.

\section{Penutup}

Dari proses analisis skripsi yang telah dijelaskan mengenai Implementasi program Pemberdayaan Usaha Garam Rakyat (PUGAR) Di Desa kedungmutih, Kecamatan Wedung, Kabupaten Demak Tahun 2011- 2013 dapat diambil beberapa kesimpulan sebagai berikut:

1. Program Pemberdayaan Usaha Garam Rakyat (PUGAR) di Desa Kedungmutih, Kecamatan Wedung, Kabupaten Demak Tahun 2011- 2013, telah mampu mencapai tujuan yang telah ditetapkan dalam program PUGAR yaitu meningkatkan produksi garam rakyat yang berpengaruh pada meningkatnya pendapatan petambak garam yang berimbas pada meningkatnya kesejahteraan petambak garam.

2. Dalam pelaksanaan program PUGAR di Desa Kedungmutih ditemui beberapa hambatan seperti petambak garam yang masih mengalami kesulitan dalam menggunakan teknologi garam, pemasaran garam rakyat masih terjerat tengkulak dan kualitas 
garam rakyat yang masih rendah yaitu KW 3.

3. Dalam mengatasi hambatan tersebut, implementor program PUGAR telah melakukan berbagai upaya seperti sosialisasi teknologi garam dan studi banding ke Cirebon. Namun, upaya yang dilakukan oleh implementor program PUGAR kurang efektif karena hingga saat ini petambak garam masih mengalami kesulitan dalam menggunakan teknologi garam dan pemasaran garam rakyat masih terjerat oleh tengkulak.

Rekomendasi yang bisa diberikan dalam pelaksanaan program PUGAR di Desa Kedungmutih, Kecamatan Wedung, Kabupaten Demak Tahun 2011- 2013 sebagai berikut :

1. Harus ada pembenahan dalam sumber daya implementor program PUGAR. Tidak hanya lulusan Sarjana Perikanan yang mengikuti pelatihan dari Kementrian Kelautan dan Perikanan tentang cara sosialisasi program PUGAR tetapi harus mengikuti pelatihan mengenai penggunaan teknologi garam. Disamping itu, Tenaga Pendamping yang paling banyak berinteraksi dengan KUGAR harus melakukan pendampingan dan praktek langsung ke tambak garam dalam menggunakan teknologi garam sehingga petambak garam lebih mengerti dan memahami dalam menggunakan teknologi garam sehingga kualitas garam rakyat mengalami peningkatan yaitu $\mathrm{KW}$ 1. Terkait dengan hambatan pemasaran garam rakyat yang masih terjerat oleh tengkulak, dibutuhkan peran serta dari Dinas Perdagangan, Perindustrian dan UMK Kabupaten Demak untuk bekerjasama dengan Dinas Kelautan dan Perikanan Kabupaten Demak dalam mendirikan KOGAR. Tidak hanya menjalin koordinasi yang baik, tetapi juga harus ada langkah yang nyata dengan melakukan pembinaan yang aktif kepada petambak garam agar petambak garam benar- benar siap dalam mengelola KOGAR sehingga KOGAR dapat berjalan lancar, berkelanjutan dan memberikan manfaat kepada KUGAR.

2. Petambak garam harus mempunyai keyakinan penuh, niat yang serius dalam mengikuti pembinaan, pengarahan, pendampingan serta sosialisasi terkait dengan kegiatan dalam pelaksanaan program PUGAR dan mulai menghilangkan presepsi yang negatif tentang program PUGAR.

\section{Daftar Pustaka}

Agustino, Leo. 2008. "Dasar- Dasar Kebijakan Publik". Bandung : Alfabeta.

Badjuri, Abdulkahar dan Teguh Yuwono. 2002. "Kebijakan Publik, Konsep dan Strategi”. Semarang : Jurusan Ilmu Pemerintahan FISIP UNDIP. 
Dunn, William N. 2003. "Analisis Kebijakan Publik, Edisi Kedua". Yogyakarta : GAJAH MADA UNIVERSITY PRESS.

Hosio, J.E. 2007. "Kebijakan Publik \& Desentralisasi Esai-Esai Dari Sorong". Yogyakarta : LAKSBANG.

Indiahono, Dwiyanto. 2009. “Kebijakan Publik, Berbasis Dyanamic Policy Analisys". Yogyakarta :IKAPI DIY.

Nugroho D, Riant. 2006. “Kebijakan Publik Untuk Negara-Negara Berkembang”. Jakarta : PT Elex Media Komputindo Kelompok Gramedia.

Subarsono, AG. 2011. "Analisis Kebijakan Publik, Konsep, Teori dan Aplikasi". Yogyakarta : PUSTAKA PELAJAR.

Sugiyono.2009. "Metode Penelitian Kuantitatif, Kualitatif dan $R$ \& $D$ ". Bandung : Alfabeta.

Widodo, Joko. 2011. "Analisis Kebijakan Publik". Malang : Bayumedi Publishing.

Winarno, Budi.2007. "Kebijakan Publik , Teori dan Proses". Jakarta : PT. Buku Kita.

Wrihatnolo, Randy R dan Riant Nugroho Dwidjowijoto. 2007.

"Manajemen Pemberdayaan, Sebuah Pengantar dan Panduan Untuk Pemberdayaan Masyarakat”. Jakarta : PT Elex Media Komputindo.

Farid Ma'ruf Muhammad dan Rindayani. 2013. "Strategi Pemberdayaan Masyarakat Melalui Program Usaha Garam Rakyat (PUGAR) Di Dinas
Kelautan dan Perikanan Kabupaten Pemekasan”. Jurnal Publika, Vol 1, No 2. http://ejournal.unesa.ac.id diakses 18 Mei 2014, pukul 14.27 WIB.

Rochwulaningsih, Yety. 2013. “ Tata Niaga Garam Rakyat Dalam Kajian Struktural”. 1 Februari 2013, Jurnal Sejarah CITRA LEKHA, Vol XVII, No 1, 59 66. $\quad$ http://journal.ipb.ac.id diakses 17 Mei 2014, pukul 18.50 WIB.

Kementrian Kelautan dan Perikanan. 2011."Pusat Data Statistik dan Informasi Kementrian dan Kelautan".

http://statistik.kkp.go.id diakses 15 Mei 2014, pukul 13.23 WIB.

Muhammad Khasan Abdurrohman. 2014. "Negara Kepulauan Impor Garam. Apa kabar Indonesia 2015.' http://writingcontest.bisnis.com diakses 15 Mei 2014, pukul 09.04 WIB. Boyke, P Siregar. 2014. "Penuhi Kebutuhan Garam Industri, KKP Dorong Potensi Pantai”. http://wartaekonomi.co.id diakses 15 Mei 2014, pukul 19.38 WIB.

Fatkhul Mukmin. 2011. "Sosialisasi PUGAR Kabupaten Demak Menuju Swasembada Garam Nasional 2012”. http://ekonomi.kompasiana.com diakses 23 Mei 2014, pukul 08.09 WIB.

Moki, Semarang. 2012. "Usaha Garam Di Jawa Tengah Terus Dikembangkan". 
http://www.kabarinvestigasi.co

$\underline{\mathrm{m}}$ diakses 18 Mei 2014, pukul 20.39 WIB.

Demak, publikasi nasional. 2011. DKP Demak Berdayakan Usaha Garam Rakyat

http://www.publiknasional.com

diakses 18 Mei 2014, pukul 21.58 WIB.

Sena. 2012. "Garam Wedung Berkelana Hingga Luar Kota".http://hariansemarangban get.com diakses 24 April 2014, diakses pukul 15.58 WIB.

Buku Profil Dinas Kelautan dan Perikanan Kabupaten Demak Tahun 2011.

Buku Profil Desa Kedungmutih Tahun 2014. 